Ethics briefings

\section{Ethics of research in developing countries}

We have previously drawn attention to evolving international research ethics and standards of care to be applied by Western researchers carrying out drug trials in developing countries. The non-provision in HIV vaccine trials of antiretroviral regimes to reduce mother-to-child transmission has been at the centre of debate. Some think that in its revised Helsinki Declaration, ${ }^{2}$ the World Medical Association (WMA) leaves the issue open to interpretation. The WMA says that "the benefits, risks, burdens and effectiveness of a new method should be tested against those of the best current methods". This can be read as supporting a universal standard of care regardless of the research location, to prevent exploitation of poor patients. In April 2002, however, the UK Nuffield Council on Bioethics published a thoughtful report arguing the contrary. While stressing the fundamental ethical principle that advantage must not be taken of the vulnerabilities created by poverty and poor resources, it said that insisting upon a universal standard of care was not the way to respect that principle. The Ethics of Research Related to Healthcare in Developing Countries, ${ }^{3}$ argues that standards of care can vary and should be defined in consultation with local people. Recommending that externally funded research should provide the level of care that is averagely available in that setting, it also envisages exceptional cases where an even lower standard would be permissible for the control group. An example is where research is to demonstrate that the best locally available treatments are ineffective or harmful. The WMA has issued one clarification note regarding Helsinki. It may now consider another to define "best current methods".

All articles written by Veronica English, Gillian Romano-Critchley, Julian Sheather and Ann Sommerville, BMA Ethics Department

\section{South Africa and antiretrovirals-a change of heart}

In April 2002, South Africa dramatically reversed its AIDS policy, announcing universal access to AIDS prophylactics for mother-to-child transmission of HIV. Previously, President Mbeki and Health Minister Tshabalala-Msimang had been notoriously sceptical about the cause of AIDS and effectiveness of antiretrovirals. In 2000 for example, Mbeki talked about the toxicity of antiretrovirals. In January 2002 , despite estimates that one in three of the population and roughly $36 \%$ of pregnant women in KwaZulu Natal were HIV positive, TshabalalaMsimang criticised its administration for making prophylactics against mother-to-child transmission of HIV freely available. ${ }^{4}$

South Africans could buy antiretrovirals privately but only 18 state hospitals prescribed them for patients although zidovudine was available to health workers exposed occupationally to HIV. Even rape victimsincluding raped babies who are especially vulnerable to HIV infectionwere denied prophylactic drugs. ${ }^{5}$ Some doctors, however, claimed an ethical duty to defy state policy. In March 2002, the World Medical Association condemned the dismissal of a doctor for providing antiretrovirals to raped women and children in contravention of government rules (World Medical Association press release: WMA condemns dismissal of South African doctor, 8 March 2002). The South African Paediatric Association estimated that 70000 babies were born with HIV in 2000 although mother-to-child transmission could be halved by prophylactics. ${ }^{6}$

Few believe that Mbeki has actually changed his views about AIDS but rather that pressure was exerted domestically and internationally, including from the African National Congress and a court ruling requiring the government to provide nevirapine. The Global Fund to Fight AIDS, Tuberculosis and Malaria, standing at \$1.9 billion, intends to disburse its first grants in Africa. Clearly it would be difficult to offer aid to a country whose health minister publicly questions the existence of the HIV virus and its link with sexual activity. Despite the apparent government volte-face, major difficulties remain, including problems of health delivery and infrastructure. Also, although some manufacturers offer prophylactics at cost price, it will cost a seventh of all state spending to treat the five million HIV infected South Africans with antiretrovirals

\section{Protecting personal genetic information}

The UK government has been advised to join the growing number of countries that have, or are considering, a "genetic non-discrimination" law. The government's advisory body, the Human Genetics Commission (HGC), launched a report $^{8}$ in May with recommendations on the use of personal genetic data. Predictably, some issues-such as genetic information in insurance and whether any, and if so what, restrictions should be applied to reproductive choiceremain unresolved and will be the subject of further discussion over the coming years. A number of the recommendations-such as those on consent and confidentiality-simply restate current good practice and existing guidance from other bodies. The report also refers to the need to consider new legislation to protect personal genetic information.

In keeping with many international statements, such as the Council of Europe's Convention on Human Rights and Biomedicine, and UNESCO's Universal Declaration on the Human Genome and Human Rights, the HGC's report supports the principle that no person should be discriminated against on the basis of genetic characteristics. In the United States, federal legislation, such as the Health Insurance and Portability Act and the Americans with Disability Act, have been interpreted as covering genetics and employment and on 8 February 2000, President Clinton signed an executive order banning genetic discrimination in federal employment. A comprehensive law banning genetic discrimination in both health insurance and employment has been proposed in the US. Amendments to existing legislation to provide similar protection is being considered in Australia. The Netherlands, France, Belgium, and Sweden have all taken 
steps to restrict the use of personal genetic information in insurance and employment. The UK government has negotiated a five year moratorium on the use of adverse genetic test results by insurance companies in connection with life insurance policies up to $£ 500000$ and other policies up to $£ 300$ 000. Before the moratorium ends in 2006, the government must consider whether to place this moratorium on a statutory footing or seek to balance the competing interests involved in some other way.

Whilst "non-discrimination" is uncontroversial and provides politicians with useful media soundbites, the crucial point is how it is interpreted. The HGC gives "discrimination" its everyday meaning of treating people differently for irrelevant reasons but says that the use of relevant information, in employment or insurance-for example, may constitute unfair discrimination if it "would have harmful social consequences". Because of concerns that people will not take genetic tests for fear of being disadvantaged by the results, the report concludes that allowing insurance companies access to genetic test results could have "damaging moral and social consequences". The HGC may be leaning towards the view that the use of genetic information by insurance companies, even if it is actuarially relevant, constitutes unfair genetic discrimination and should be prohibited.

Coming hard on the heels of newspaper reports of the theft of used dental floss in order to obtain DNA for paternity testing, ${ }^{9}$ the HGC report recommends the introduction of a new criminal offence of obtaining and testing a person's DNA without consent. Which rummaging through rubbish bins in search of DNA may be an extreme step most people would not choose to take, taking a hair containing the hair follicle from a person's hairbrush, or picking up a used glass or cup may be a relatively easy way of covertly obtaining a DNA sample. In the UK, companies offering paternity testing are regulated by a voluntary code of practice with detailed requirements on consent and confidentiality and simple methods of identification to minimise the risk of nonconsensual testing. The increasing ease with which people may access genetic testing in other countries, however, where the safeguards on consent are less strict (including paternity testing via the internet) has been highlighted as a cause for concern.

The report also addresses the forensic uses of DNA samples. Since 1995 the UK police have held a National DNA Database containing the genetic profiles of those people suspected of "recordable offences" that would lead, on conviction, to a prison sentence. Initially, the police focused on serious crimes, such as murder and sexual offences but increasingly samples have been taken from those suspected of less serious offences. Originally, the samples of those acquitted had to be destroyed but since the Criminal Justice and Police Act 2001 came into force both the original sample and the genetic profile derived from it may be retained, whatever the outcome of the case. The report points out that a combination of these new powers and increased funding being devoted to developing the database, could lead to a young person being arrested, but not charged, for a minor crime which would result in that person's DNA profile being retained on the National DNA Database for his or her entire life. The HGC has expressed concern that when people are asked to volunteer for mass screening in order to prove their innocence, they are now asked to sign a consent form allowing the profile to be retained, and this consent cannot subsequently be revoked. Whilst the public supports the use of a DNA database for detecting serious crimes, its use for less serious crimes needs further debate to find an appropriate balance between the public interest and individual privacy.

\section{Assisted suicide}

Dianne Pretty ${ }^{10}$ lost the final stage of her battle against the UK's prohibition on assisted suicide on 29 April 2002. ${ }^{11}$ The European Court of Human Rights dismissed claims that article 2 of the European Convention on Human Rights $^{12}$ protected not only the right to life but also the right to choose whether or not to go on living. At a time when Belgium was voting to legalise euthanasia, ${ }^{13}$ Mrs Pretty argued that allowing her assistance in committing suicide could not conflict with article 2 because otherwise those countries in which assisted suicide was lawful would breach this provision. The court acknowledged that the extent to which a state permits, or regulates, the possibility for the infliction of harm on individuals raised conflicting considerations of personal freedom and public interest that could only be resolved on examination of the concrete circumstances of the case. It concluded, however, that even if the circumstances prevailing in a particular country did not infringe article 2 , the proposition that the UK breached its obligations by not permitting assisted suicide was a different issue.

\section{References}

1 English V, Heath L, Romano-Critchley G, et al. Ethics briefings: Revision of the Helsinki Declaration. Journal of Medical Ethics 2000;26:139-40. English V, Gardner G, Romano-Critchley $G$, et al. Ethics briefings: Helsinki Declaration on medical research. Journal of Medical Ethics 2001 ;27:284-5.

2 Declaration of Helsinki. World Medical Association, 2000. www.wma.net/e/policy/ 17-c_e.htm.

3 Nuffield Council on Bioethics. The ethics of research related to healthcare in developing countries. London: Nuffield Council on Bioethics, 2002. www.nuffieldbioethics.org/ developingcountries. Accessed 28 May 2002

4 Ashraf H. S Africa state offers HIV drug to pregnant women. Lancet 2002;359:416.

5 Reason prevails. The Economist 2002 Apr 27: 85.

6 Connor EM, Sperling RS, Gelber R, et al. Reduction of maternal-infant transmission of human immunodeficiency virus type 1 with zidovudine treatment. New England Journal of Medicine 1994;331:1173-80.

7 Pretoria High Court ruling, 25 March 2002. BBC online 200225 March. http://news.bbc.co.uk. Accessed 28 May 2002.

8 Human Genetics Commission. Inside Information-balancing interests in the use of personal genetic data. London: HGC, 2002.

9 Engel $M$. Bing sues MGM boss for $\$ 1$ bn over bin search in new paternity case. The Guardian 2002 May 18: 2.

10 For previous briefings on this case, see: English V, Romano-Critchley G, Sheather J, et al. Ethics briefings: Human rights and assisted suicide. Journal of Medical Ethics 2002;28:53-4, and: English V, Romano-Critchley G, Sheather J, et al. Ethics briefings: Assisted suicide. Journal of Medical Ethics 2002;28:127-8.

11 European Court of Human Rights. Pretty $v$ The United Kingdom (application no 2346/02).

12 Convention for the Protection of Human Rights and Fundamental Freedoms (4 ix. 1950; TS 71; Cmnd 8969).

13 Belgium legalises euthanasia. $B B C$ online 200216 May. http://news.bbc.co.uk. Accessed 28 May 2002. 